\title{
Predictive power of indicators to the perception of food and nutritional insecurity in the Bolsa Família Program
}

\author{
Poder preditivo de indicadores à percepção de insegurança \\ alimentar e nutricional no Programa Bolsa Família
}

\begin{abstract}
Daiane Roncato Cardozo ${ }^{1}$ (D), Sinara Laurini Rossato ${ }^{2,3}$ (D), Maria Rita Marques de Oliveira ${ }^{4}$ (D), Vera Mariza Henriques de Miranda Costa $^{5}$ (D), Luiz Manoel de Moraes Camargo Almeida ${ }^{6}$ (D), Luiz Fernando de Oriani e Paulillo ${ }^{7}$ (D) Araraquara, SP, Brasil. E-mail: daianecardozo@msn.com
2Universidade Estadual Paulista "Júlio Mesquita Filho" - UNESP, Faculdade de Medicina, Programa de Pós-graduação em Enfermagem, Botucatu, SP, Brasil. E-mail: sinara.Irossato@gmail.com
${ }^{3}$ Harvard T.H. Chan School of Public Health, Departament of nutrition, Boston, MA, United States of America.
“Universidade Estadual Paulista “Júlio Mesquita Filho" - UNESP, Faculdade de Medicina, Departamento de Educação, Botucatu, SP, Brasil. E-mail: mrmolive.unesp@gmail.com
${ }^{5}$ Universidade de Araraquara, Programa de Mestrado Profissional em Engenharia de Produção, Araraquara, SP, Brasil. E-mail: verammcosta@uol.com.br
${ }^{6}$ Universidade Federal de São Carlos - UFSCar, Centro de Ciências da Natureza, Campus Lagoa do Sino, Buri, SP, Brasil. E-mail: manoel77@yahoo.com.br
7Universidade Federal de São Carlos - UFSCar, Programa de Pós-graduação em Engenharia de Produção, São Carlos, SP, Brasil. E-mail: dlfp@power.ufscar.br

${ }^{1}$ Universidade de Araraquara, Programa de Pós-graduação em Desenvolvimento Territorial e Meio Ambiente,
\end{abstract}

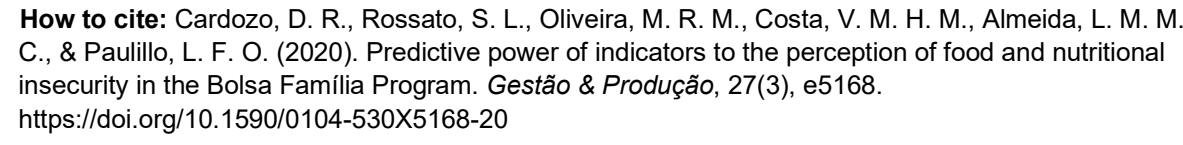

\begin{abstract}
The objective was to analyze the predictive power of indicators of the perception of food and nutritional insecurity comparing beneficiary and non - beneficiary families of the Bolsa Família Program, through a cross - sectional study with 150 families. Demographic, socioeconomic, food insecurity (Brazilian Food Insecurity Scale), nutritional status (Body Mass Index) and household consumption patterns were collected. The correlation between the demographic, socioeconomic, nutritional status and level of food insecurity were tested using the Pearson correlation coefficient; the association with Chi-square and ANOVA tests; and the prevalence ratio and 95\% confidence intervals with Poisson Regression model. The predictive power of indicators of food insecurity was evaluated with the ROC curve. Patterns of food consumption, demographic and health characteristics were not significantly correlated with food insecurity. In the analyzes with the ROC curve, among the beneficiary families, the income derived only from the Bolsa Família and the Renda Cidadã Program with the Bolsa Família presented a better predictive power of food insecurity, covering the curve by $70 \%$, followed by the difference between the income from wages and rent and gas (70\%). The proportions of the total income of families spent on rent and gas had low predictive power $(67 \%)$. Income components, mainly rent and gas spending, showed a better performance in the prediction of
\end{abstract}

Received Oct. 20, 2018 - Accepted Jan. 3, 2019

Financial support: To the Coordination for the Improvement of Higher Education Personnel - CAPES, the Social Demand Program $\mathrm{DSP}$, for the granting of the Ph.D. scholarship to carry out the research. 
food insecurity among beneficiaries of Bolsa Família, and could be a complementary quantitative indicator to the Brazilian Scale of Food Insecurity.

Keywords: Food and nutrition security; Social policy; Family income; ROC curve.

Resumo: O objetivo foi analisar o poder preditivo de indicadores da percepção de insegurança alimentar e nutricional comparando famílias beneficiárias e não beneficiárias do Programa Bolsa Família, por meio de estudo transversal com 150 famílias. Foram coletadas informações demográficas, socioeconômicas, de insegurança alimentar (Escala Brasileira de Insegurança Alimentar), do estado nutricional (Índice de Massa Corporal) e do padrão de consumo alimentar das famílias. A correlação entre as características demográficas, socioeconômicas, estado nutricional e o nível de insegurança alimentar foram testadas com o coeficiente de correlação de Pearson; a associação com testes Qui-quadrado e ANOVA; e a razão de prevalência e intervalos de confiança de $95 \%$ com modelo de Regressão de Poisson. O poder preditivo de indicadores de insegurança alimentar foi avaliado com a Curva ROC. Padrões de consumo alimentar, características demográficas e de saúde não foram significativamente correlacionados com insegurança alimentar. Nas análises com a curva ROC, entre as famílias beneficiárias, a renda oriunda somente do benefício do Bolsa Família e do Programa Renda Cidadã com o Bolsa Família apresentou melhor poder preditivo de insegurança alimentar, cobrindo a curva em $70 \%$, seguida pela diferença entre a renda oriunda do salário e o gasto com aluguel e gás (70\%). As proporções da renda total das famílias gastas com aluguel e gás apresentaram baixo poder preditivo (67\%). Componentes da renda, principalmente o gasto com aluguel e gás, mostraram melhor desempenho na predição de insegurança alimentar entre beneficiários do Bolsa Família, podendo constituir-se como um indicador quantitativo complementar à Escala Brasileira de Insegurança Alimentar.

Palavras-chave: Segurança alimentar e nutricional; Política social; Renda familiar; Curva ROC.

\section{Introduction}

The human right to adequate food, food sovereignty and food and nutritional security (FNS) are concepts that have been built and improved worldwide since the beginning of the 20th century with the creation of the United Nations Food and Agriculture Organization (FAO), to fight hunger and achieve greater social justice, health and quality of life of the population. Such concepts encompass dimensions related to access, availability, use, and stability of food within a territory, which must be articulated through projects, programs, laws and cooperation networks regarding the production, distribution, choice, preparation, consumption and its relation with health, environmental conditions and biological use of food (Gross et al., 2000; Ziegler, 2003; Brasil, 2006).

The Panorama de la Seguridad Alimentaria y Nutricional en América Latina y el Caribe, in 2017, shows that after many years of remarkable progress in reducing hunger, there has been a stagnation in the period 2011-2013, with an increase in the proportion of undernourished from $10.6 \%$ in 2015 to $11 \%$ in 2016, increase of 38 million people, in parallel with the increase in the rate of overweight and obesity in adults, especially in women, between 1980 and 2014 (about 20\% above the population) and the rate of children over 5 years old, $7 \%$ higher than the world average (ONU/FAO, 2017).

In Brazil, despite the progress made in reducing child hunger and malnutrition in the FAO report, 2014, food insecurity (FI) still persists, being associated with vulnerabilities and social risks over living conditions, mainly in relation to income, schooling, work, 
and basic sanitation (ONU/FAO, 2014; IBASE, 2009; Traldi et al., 2012; Cardozo, 2016; Sperandio \& Priore, 2015; Cotta \& Machado, 2013).

As a way to promote, evaluate and monitor the FNS of the Brazilian population, the Brazilian government has implemented policies and programs that have been successful in its results. Examples are health programs in schools, supplementation, supply (basic food baskets, popular restaurants, banks, vegetable gardens, and communal kitchens), financing (National Program for Strengthening Family Agriculture - NPSFA), and income transfer, like the Bolsa Família Program - BFP (Brasil, 2017).

The BFP is the largest Brazilian social program, which seeks to benefit families living in poverty and extreme poverty, registered in the Single Register for Social Programs of the Federal Government (Single Database). On the other hand, families must make a commitment to prioritize education, by guaranteeing school attendance; health, vaccine coverage, prenatal care, and child growth; and social inclusion, through socio-educational activities.Studies present the importance and influence of BFP in the living conditions of families, especially those focused on food acquisition (IBASE, 2009; Traldi et al., 2012; Cardozo, 2016; Sperandio \& Priore, 2015; Cotta \& Machado, 2013). It is worth mentioning that the beneficiary families of the BFP with per capita income up to $25 \%$ of the minimum wage also receive the State Renda Cidadã Program (RCP), which has the same counterpart as the BFP in relation to the school attendance of the children and activities of all members of the family.

To evaluate the $\mathrm{FI}$ of individuals, family or a population, some methods have been used in several countries, presenting discrepancies between them according to the different dimensions of FNS: FAO method, Family Budget Survey (FBS), Individual Ingestion Survey Food, Anthropometric Research, and Food Insecurity Perception Research (Hu \& Willett, 2002; Anderson, 1990; Galesi et al., 2009; Vannier-Santos, 2007; Pérez-Escamilla \& Segall-Corrêa, 2008; Lignani et al., 2011; Jones et al., 2013).

The Brazilian Food Insecurity Scale (BFIS) is the instrument used to evaluate FI in population environments, asking the family member questions about food access and availability, and classifying families at different levels of food security (FS), light food insecurity (LFI), moderate food insecurity (MFI) and severe food insecurity (SFI). BFIS is widely applied in the country due to its internal and external validity and consistency, reflecting the individual FI perspective (Segall-Corrêa, 2007; Segall-Corrêa \& Marin-León, 2009; Segall-Corrêa et al., 2003).

Therefore, this study had the objective of analyzing the predictive power of indicators of perceived food and nutritional insecurity of beneficiary and non-beneficiary families of the BFP, assisted by a Social Assistance Reference Center (SARC) in the interior of the state of São Paulo (SP). Thus, one of the specific objectives was to test which indicators, which not only by the perception of income availability and food availability (falling into subjectivity), could complement EBIA.

\section{Metodology}

The research took place between 2015 and 2016. In the municipality of Araraquara-SP, in 2015, the Single Database presents 11,000 families enrolled in the different social programs of the Brazilian government, of which 3,700 are beneficiaries of the BFP. The care of these families is the responsibility of the Municipal Department of Social Assistance and eight SARC (Social Assistance Reference Center), located in peripheral neighborhoods around the municipality. The SARC Parque São Paulo, the subject of this 
study, comprises about 700 families enrolled in the Single Database and 400 beneficiary families of the BFP.

The population was divided into two groups: BFP beneficiary families for 2 years or more, composed of 3 members $(n=113)$, and non-beneficiary families, but registered to receive it, also composed of 3 members $(n=77)$. According to the local manager of the BFP, the criterion adopted for the delimitation of beneficiary families, considering their entry into the program for two years or more is the minimum time for evaluating the effects of the BFP (Cardozo, 2016). The choice for the size of the families was due to the representativeness of the family composition, being 3 members in this unit of study.

Data collection occurred in 2015. During the scheduling, it was verified that some families would not participate in the survey due to different field occurrences (8 families moved to other neighborhoods, 24 families changed the number of members, 3 families had the benefit canceled, 4 non-beneficiary families began to receive the benefit, and one did not agree to participate in the research). Thus, the sample represented $88 \%$ of the beneficiary population $(n=100)$ and $65 \%$ of the non-beneficiary population $(n=50)$, totaling 150 families (Figure $1 \mathrm{~A}$ - Appendix $\mathrm{A}$ ).

The form used in the research took as a reference the methods and instruments already validated in other studies that include demographic, socioeconomic, anthropometric and food consumption indicators (IBASE, 2009; Traldi et al., 2012; Segall-Corrêa et al., 2003; IBGE, 2004). The anthropometric data (weight and height) were collected only from the cardholder, using a Tanita digital weighing scale with a capacity of $150 \mathrm{~kg}$ on a smooth and leveled surface and a portable stadiometer measuring 2 meters in height, placed on a smooth wall without a skirting board, with the paper ruler provided by the Network for the Defense and Promotion of Healthy, Adequate and Solidarity Food (SANS Network).

In order to classify the subjects' nutritional status, the Body Mass Index (BMI), for adults and the elderly, was used according to the cut-off points proposed by the World Health Organization (WHO) for each age group and gender (Brasil, 2011). Food consumption was assessed qualitatively by the frequency of consumption of 32 kinds of food in the 7 days prior to the information retrieval. Foods were categorized into 12 groups based on the study of the Brazilian Institute of Social and Economic Analysis (IBASE, 2009).

Data were evaluated with SPSS $\AA$ software version 23 for Windows. The classification of food and nutritional insecurity assessed by BFIS, categorized as food security or light food insecurity (SF/LFI) and moderate or severe food insecurity (MFI/SFI), was used as the outcome variable.

The Pearson correlation coefficient was used to test the relationship between the explanatory variables (total expenditures at home, proportion of the total income spent on education, rent, gas, water, electricity, health, telephone and other expenses, proportion of income from the salary, the BFP and the Renda Cidadã Program - of income transfer to families with per capita income up to $25 \%$ of the minimum wage; difference in BFP income and expenses with food, gas and rent; difference in RCP income and expenses with food, gas and rent; difference in salary income and expenses with food, gas and rent; the difference between the income of the BFP and RCP and expenses with food, gas and rent) with FS/LFI or MFI/SFI, in order to justify the inclusion of the variables selected in the ROC (Receiver Operating Characteristic) curve analysis. The correlation force levels were determined according to the criteria of Altman (1991). The association was performed with Chi-square and ANOVA tests; and the prevalence ratio and $95 \%$ confidence intervals with Poisson Regression model. 
The ROC Curve has this name because it compares the behavior of alteration of two operational characteristics of the model (sensitivity and specificity). It was initially developed and used by engineers in World War II to detect enemy objects in battles. Later, it was introduced in Psychology to detect perceptions of some stimuli and is currently widely used in radiology and applied social sciences, such as Economics and Finance (Swets, 1996 apud Fávero \& Belfiore, 2017).

In medicine, it is used to test diagnostic methods for diseases by assessing the sensitivity, represented by the true positive rate, and the specificity, represented by the false negative rate (Zweig \& Campbell, 1993). Each point on the curve represents the connection between the sensitivity and specificity values of the diagnostic test, generating a decision limit. The percentage of the area under the ROC Curve signals the proportion of the correctly diagnosed population, with a coverage of at least $70 \%$ acceptable (Martinez et al., 2003).

Thus, this study proceeds to analyze, through the ROC curve, the BFP indicators for the classification of families with FI levels, the income being the indicator equivalent to the diagnostic method and the MFI / SFI levels equivalent to the presence of the disease.

Sensitivity analyses were performed to evaluate the best analytical model. Pearson's correlation coefficient was tested between food patterns and consumption of items and food groups with the BFIS. There was no significant correlation, thus not justifying the evaluation of these variables as indicators of FI. Variables based on other studies were also tested, such as socioeconomic and demographic indicators for FI (IBASE, 2009; Galesi et al., 2009; Vannier-Santos, 2007; Pérez-Escamilla \& Segall-Corrêa, 2008). However, the income and its components (sources and expenses) were the variables that presented higher correlation coefficients and more significant statistically.

The present work was approved by the Committee of Ethics in Research (CER) with Human Beings of the Faculty of Pharmaceutical Sciences, the State University of São Paulo, Campus of Araraquara, São Paulo, Brazil, under the opinion $n^{\circ} 847.071$, of October 14, 2014.

\section{Results}

Based on the analysis of the data of the responses of the families participating in the study (Table 1), $25 \%$ of the beneficiaries of the BFP were classified as FS/LFI among the families participating in the study, while $62 \%$ of the families that were not beneficiaries had MFI/SFI. In an unadjusted analysis, the proportion of families in $\mathrm{FS} / \mathrm{LFI}$ and MFI/SFI situations was not statistically different according to whether they were beneficiaries or not. Also, no significant differences were found in the proportion of families classified in the two categories (FS/LFI and MFI/SFI) according to the other variables. However, it was observed that $76 \%$ of the families that spent less than $15 \%$ of the total income with gas and rent were in MFI/SFI, whereas only $24 \%$ of these families were FS/LFI ( $p=0.02$ ). In addition, $81 \%$ of the families that earned more than one minimum wage was in MFI/SFI, and only $19 \%$ of these families were in FS/LFI $(p=0.03)$. 
Table 1. Characteristics of the beneficiary and non-beneficiary families of the BFP.

\begin{tabular}{|c|c|c|c|}
\hline & \multicolumn{2}{|c|}{ BFIS } & \multirow{2}{*}{ p-value } \\
\hline & FS/LFI & MFI/SFI & \\
\hline Bolsa Família Program & & & 0.10 \\
\hline Yes & $25(25)$ & $75(75)$ & \\
\hline No & $19(38)$ & $31(62)$ & \\
\hline Family Origins & & & 0.60 \\
\hline North / Northeast / Center-West & $13(33)$ & $27(68)$ & \\
\hline Southeast / South & $31(28)$ & $79(72)$ & \\
\hline Housing situation & & & 0.30 \\
\hline Own home & $19(26)$ & $55(74)$ & \\
\hline Rented or leased & $24(33)$ & $48(67)$ & \\
\hline Dwelling time & & & 0.40 \\
\hline$\leq 5$ years & $25(32)$ & $52(68)$ & \\
\hline$>5$ years & $19(26)$ & $54(74)$ & \\
\hline Number of rooms & & & 0.60 \\
\hline$\leq 4$ rooms & $9(26)$ & $26(74)$ & \\
\hline$>4$ rooms & $35(30)$ & $80(70)$ & \\
\hline Holder skin color & & & 0.50 \\
\hline White & $30(31)$ & $66(69)$ & \\
\hline Black/Brown & $14(26)$ & $40(74)$ & \\
\hline Marital status of the holder & & & 0.60 \\
\hline Single & $16(27)$ & $43(73)$ & \\
\hline With partner & $28(31)$ & $63(69)$ & \\
\hline Number of children & & & 0.20 \\
\hline No children & $7(44)$ & $9(56)$ & \\
\hline From 1 to 2 children or young people & $37(28)$ & $97(72)$ & \\
\hline Holder's schooling & & & 0.40 \\
\hline$<10$ years & $18(26)$ & $52(74)$ & \\
\hline$\geq 10$ years & $26(33)$ & $54(68)$ & \\
\hline Aid in the form of food & & & 0.10 \\
\hline Yes & $19(37)$ & $32(63)$ & \\
\hline No & $25(25)$ & $74(75)$ & \\
\hline Holder's employment situation & & & 0.20 \\
\hline Employed/Self-employed & $22(25)$ & $66(75)$ & \\
\hline Unemployed & $22(35)$ & $40(65)$ & \\
\hline Proportion of total income spent on cooking gas & & & 0.50 \\
\hline$<4 \%$ & $23(27)$ & $62(73)$ & \\
\hline$\geq 4 \%$ & $21(32)$ & $44(68)$ & \\
\hline Proportion of total income spent on rent & & & 0.06 \\
\hline$<10 \%$ & $30(26)$ & $87(74)$ & \\
\hline$\geq 10 \%$ & $14(42)$ & $19(58)$ & \\
\hline Proportion of total income spent on gas and rent & & & 0.02 \\
\hline$<15 \%$ & $28(24)$ & $87(76)$ & \\
\hline$\geq 15 \%$ & $16(46)$ & $19(54)$ & \\
\hline Proportion of total income spent on food & & & 1.00 \\
\hline$<40 \%$ & $21(27)$ & $56(73)$ & \\
\hline$\geq 40 \%$ & $16(28)$ & $42(72)$ & \\
\hline Proportion of total income spent on water & & & 0.80 \\
\hline$<7 \%$ & $27(28)$ & $68(72)$ & \\
\hline$\geq 7 \%$ & $16(31)$ & $36(69)$ & \\
\hline Proportion of total income spent on electric energy & & & 0.50 \\
\hline$<10 \%$ & $23(27)$ & $62(73)$ & \\
\hline$\geq 10 \%$ & $20(32)$ & $43(68)$ & \\
\hline Proportion of total income spent on education & & & 0.90 \\
\hline$<2.5 \%$ & $33(29)$ & $79(71)$ & \\
\hline$\geq 2.5 \%$ & $9(28)$ & $23(72)$ & \\
\hline
\end{tabular}


Table 1. Continued...

\begin{tabular}{|c|c|c|c|}
\hline & \multicolumn{2}{|c|}{ BFIS } & \multirow{2}{*}{ p-value } \\
\hline & FS/LFI & MFI/SFI & \\
\hline \multicolumn{3}{|c|}{ Proportion of total income spent with health } & \multirow[t]{3}{*}{0.10} \\
\hline$<4 \%$ & $36(34)$ & $71(66)$ & \\
\hline$\geq 4 \%$ & $8(21)$ & $30(79)$ & \\
\hline \multicolumn{3}{|c|}{ Proportion of total income spent with telephone } & \multirow[t]{3}{*}{0.60} \\
\hline$<2 \%$ & $34(31)$ & $77(69)$ & \\
\hline$\geq 2 \%$ & $10(26)$ & $29(74)$ & \\
\hline \multicolumn{3}{|c|}{ Proportion of total income spent on other expenses } & \multirow[t]{3}{*}{0.30} \\
\hline$<8 \%$ & $32(32)$ & $68(68)$ & \\
\hline$\geq 8 \%$ & $11(23)$ & $36(77)$ & \\
\hline \multicolumn{3}{|l|}{ Total monthly income } & \multirow[t]{3}{*}{0.03} \\
\hline$<1$ minimum wage & $34(35)$ & $62(65)$ & \\
\hline$\geq 1$ minimum wage & $10(19)$ & $44(81)$ & \\
\hline \multicolumn{3}{|c|}{ Monthly income from Bolsa Família (\%) } & \multirow[t]{3}{*}{0.60} \\
\hline$<15 \%$ & $26(28)$ & $68(72)$ & \\
\hline$\geq 15 \%$ & $18(32)$ & $38(68)$ & \\
\hline \multicolumn{3}{|c|}{ Monthly income from Renda Cidadã (\%) } & \multirow[t]{3}{*}{0.30} \\
\hline$<4 \%$ & $33(28)$ & $87(73)$ & \\
\hline$\geq 4 \%$ & $11(37)$ & $19(63)$ & \\
\hline \multicolumn{3}{|c|}{ Monthly income from wage (\%) } & \multirow[t]{3}{*}{0.60} \\
\hline$<15 \%$ & $30(28)$ & $77(72)$ & \\
\hline$\geq 15 \%$ & $14(33)$ & $29(67)$ & \\
\hline \multicolumn{3}{|c|}{ Monthly income from Bolsa Família and Renda Cidadã (\%) } & \multirow[t]{3}{*}{0.30} \\
\hline$<20 \%$ & $23(26)$ & $66(74)$ & \\
\hline$\geq 20 \%$ & $21(34)$ & $40(66)$ & \\
\hline \multicolumn{3}{|c|}{ Difference between the expenditure on food and the monthly salary $(\mathrm{R} \$)$} & \multirow[t]{3}{*}{0.30} \\
\hline$<\mathrm{R} \$ 330.00$ & $21(32)$ & $45(68)$ & \\
\hline$\geq \mathrm{R} \$ 330.00$ & $16(23)$ & $53(77)$ & \\
\hline \multicolumn{3}{|c|}{ Difference between the expenditure on gas and the monthly salary $(\mathrm{R} \$)$} & \multirow[t]{3}{*}{0.04} \\
\hline$<\mathrm{R} \$ 580.00$ & $20(40)$ & $30(60)$ & \\
\hline$\geq \mathrm{R} \$ 580.00$ & $24(24)$ & $76(76)$ & \\
\hline \multicolumn{3}{|c|}{ Difference between the rent expense and the monthly salary $(R \$)$} & \multirow[t]{3}{*}{$<0.03$} \\
\hline$<\mathrm{R} \$ 530.00$ & $25(43)$ & $33(57)$ & \\
\hline$\geq \mathrm{R} \$ 530.00$ & $19(21)$ & $73(79)$ & \\
\hline
\end{tabular}

BFP - Bolsa Família Program; LFI - Light Food Insecurity; FS - Food Security; MFI - Moderate Food Insecurity; SFI - Severe Food Insecurity; BFIS - Brazilian Food Insecurity Scale.

Regarding the difference between family income and expenses, $21 \%$ of the families with a difference greater than $R \$ 530.00$ between rent and monthly wage income were in $\mathrm{FS} / \mathrm{LFI}$, and $79 \%$ were in MFI/SFI $(p=<0.03)$, showing that the higher the difference between rent and gas expenses and the higher the proportion of families in MFI/SFI.

Based on the correlations found between income characteristics (total household expenditures in relation to income sources - salary, BFP, RCP and other benefits - sources of income in relation to family expenses - gas, rent, education, water, energy, health, telephone and others - proportion of each source of income in relation to total income and differences between sources of income in relation to expenses with food, gas and rent) with the levels of $\mathrm{FI}$, the variables were tested as predictors of FI using a ROC curve. The means, standard deviations, and correlations between income-related variables and FI levels (Table 1B - Appendix B) were performed. Food habits measured by means of estimates of dietary patterns, the frequency of consumption of items and food groups, demographic and health characteristics were tested for correlation with FI levels (Cardozo, 2016); however, there was no significant correlation, thus not justifying to include them in the ROC Curve analyzes as $\mathrm{Fl}$ indicators. 
There was a negative correlation between total household expenditures and FI levels $(r=-0.17$ and $p=0.03)$, which, despite being a low correlation, was statistically significant. An inverse correlation $(r=-0.30 ; p<0.01)$ was observed between the family wage and FI levels in the analysis with the whole sample, and this correlation was even stronger in the analysis of the group of beneficiary families of the BFP. Regarding the proportion of total income spent on gas, rent, food, energy and education, a positive correlation was found only for the proportion of income spent on gas and FI levels $(r=0.23, p=<0.05)$. In addition, the sum of the proportion of total rent spent on rent and gas was even more significant, for both the full sample $(r=0.35, p<0.01)$ and for the beneficiary families $(r=0.34 ; p<0.01)$ and non-BFP beneficiaries $(r=0.35, p=0.01)$. The energy expenditure was significant for the entire sample and for the beneficiary families of the BFP, but not for the non-beneficiary families (Table 1B - Appendix B).

The difference between the income of BFP beneficiaries, RCP and salary, and household expenses with rent, gas, food, electricity, water, education, health, telephone and other expenses (data not shown) were analyzed.However, only the difference between income and expenditure on food, gas, and rent were significantly correlated with $\mathrm{FI}$, either in the whole sample or in the stratified analysis. For this reason, the difference between income and expenditures with other indicators was not presented and, although the proportions of energy expenditures were significantly correlated with $\mathrm{FI}$, the difference between income and cost with electric energy was not included in the analysis using the ROC Curve, because there was no significant correlation with the levels of FI (Table 1B - Appendix B).

Regarding the difference between the BFP income and the feeding expenses, a positive correlation was observed in the whole sample $(r=0.24, p=<0.05)$, as well as the difference between the RCP income and the feeding expenses $(r=0.32, p=<0.01)$, both for BFP beneficiary families $(r=0.34, p=<0.01)$ and for non-beneficiary families $(r=0.36 ; p=0.02)$. The positive correlation was also found for the difference between the joint incomes of the two programs $(r=0.25, p=<0.03)$ (Table 1B - Appendix B).

Table 2 shows the variables analyzed as indicators of food and nutritional insecurity using the ROC curve analysis (expressed by Figures 1, 2 and 3).

Table 2. Analysis of the predictive power of potential food insecurity indicators for the BFP.

\begin{tabular}{ccc}
\hline & $\begin{array}{c}\text { Measurement of the } \\
\text { area under the ROC } \\
\text { curve (CI 95\%) }\end{array}$ & p-value \\
\hline De acordo com o gasto proporcional à renda total com: & & \\
Gas & $0.60(0.50-0.70)$ & 0.06 \\
Rent & $0.58(0.47-0.68)$ & 0.10 \\
Rent and Gas & $0.67(0.58-0.77)$ & $<0.01$ \\
\hline Expenditure proportional to the total income of Bolsa Familia & & \\
beneficiary families: & $0.64(0.51-0.77)$ & $\mathbf{0 . 0 4}$ \\
Gas & $0.54(0.40-0.67)$ & 0.60 \\
Rent & $0.68(0.56-0.80)$ & $\mathbf{0 . 0 1}$ \\
Rent and Gas & & \\
\hline Expenditure proportional to the total income of families not & & \\
beneficiaries of Bolsa Familia: & $0.55(0.38-0.72)$ & 0.60 \\
Gas & $0.63(0.47-0.80)$ & 0.10 \\
Rent & $0.67(0.52-0.83)$ & $\mathbf{0 . 0 4}$ \\
\hline Rent and Gas &
\end{tabular}


Table 2. Continued...

\begin{tabular}{|c|c|c|}
\hline & $\begin{array}{l}\text { Measurement of the } \\
\text { area under the ROC } \\
\text { curve (Cl } 95 \%)\end{array}$ & p-value \\
\hline \multicolumn{3}{|l|}{$\begin{array}{l}\text { According to the total income proportional to the source of } \\
\text { income }\end{array}$} \\
\hline Benefits of Bolsa Família & $0.51(0.40-0.62)$ & 0.90 \\
\hline Benefits of Renda Cidadã Program & $0.53(0.43-0.64)$ & 0.50 \\
\hline Wage & $0.54(0.44-0.64)$ & 0.50 \\
\hline Benefits of Bolsa Família and Renda Cidadã & $0.56(0.45-0.67)$ & 0.30 \\
\hline \multicolumn{3}{|c|}{$\begin{array}{l}\text { Total income proportional to the source of income of beneficiary } \\
\text { families of Bolsa Familia }\end{array}$} \\
\hline Benefits of Bolsa Família & $0.70(0.57-0.82)$ & $<0.03$ \\
\hline Benefits of Renda Cidadã Program & $0.52(0.39-0.65)$ & 0.80 \\
\hline Wage & $0.61(0.48-0.74)$ & 0.10 \\
\hline Benefits of Bolsa Família and Renda Cidadã & $0.70(0.59-0.82)$ & $<0.02$ \\
\hline \multicolumn{3}{|c|}{$\begin{array}{c}\text { Total income proportional to the source of income of families not } \\
\text { beneficiaries of Bolsa Familia }\end{array}$} \\
\hline Benefits of Renda Cidadã Program & $0.57(0.40-0.74)$ & 0.40 \\
\hline Wage & $0.47(0.31-0.63)$ & 0.70 \\
\hline \multicolumn{3}{|c|}{$\begin{array}{c}\text { According to the difference between the salary and the expense } \\
\text { with: }\end{array}$} \\
\hline Food & $0.57(0.46-0.68)$ & 0.20 \\
\hline Rent & $0.67(0.56-0.77)$ & $<0.03$ \\
\hline Gas & $0.62(0.51-0.73)$ & 0.03 \\
\hline \multicolumn{3}{|l|}{$\begin{array}{c}\text { Difference between the salary and the expenses with the } \\
\text { expenses of beneficiary families of Bolsa Familia }\end{array}$} \\
\hline Rent & $0.74(0.62-0.85)$ & $<0.01$ \\
\hline Food & $0.69(0.56-0.81)$ & 0.01 \\
\hline Gas & $0.72(0.60-0.85)$ & $<0.02$ \\
\hline \multicolumn{3}{|l|}{$\begin{array}{l}\text { Difference between salary and expenses with expenses of } \\
\text { families not beneficiaries of Bolsa Familia }\end{array}$} \\
\hline Rent & $0.68(0.51-0.85)$ & 0.04 \\
\hline Food & $0.47(0.29-0.65)$ & 0.70 \\
\hline Gas & $0.59(0.41-0.77)$ & 0.30 \\
\hline
\end{tabular}

ROC Curve - Receiver Operating Characteristic Curve; Cl 95\% - Confidence Interval.

Figure 1 shows that, in relation to household expenditures, the proportions of total income spent on rent and gas did not perform well in predicting $\mathrm{FI}$ levels, covering approximately $67 \%$ of the area under the curve $(95 \% \mathrm{Cl} 0.58-0.77, \mathrm{p}=<0.01)$.In the beneficiary families, the proportion of total income spent on gas, and rent and gas, performed similarly, covering 64\% (IC95\% 0.51-0.77; $p=0.04)$ and 68\% (IC95\% 0.56-0.80; $p=0.01$ ) of the area under the curve, as observed for non-beneficiary families, in relation to the proportion of total income spent on rent and gas (IC95\% 0.52-0.83; $p=0.04$ ). 

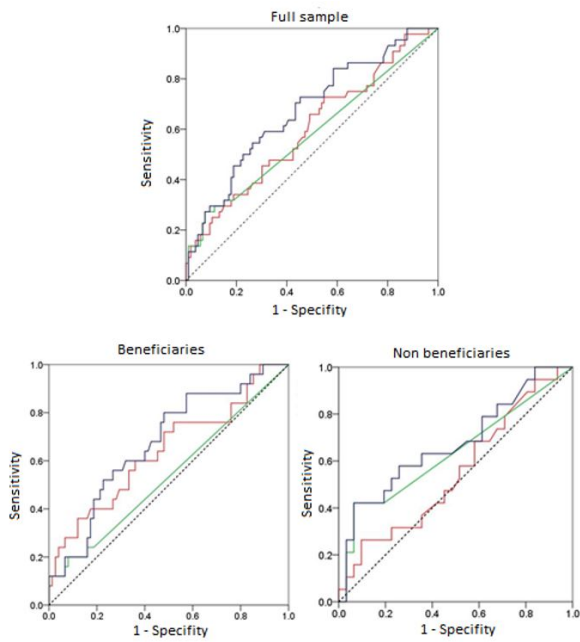

-Proportion of total income spent on gas

- Proportion of total income spent on rent

- Proportion of total income spent on rent and gas

...50\% cutoff point for sensitivity and specificity

Figure 1. Proportion of total household income spent on gas and rent.

On the other hand, Figure 2 presents the FI in relation to household sources of income (complete and stratified sample - beneficiaries and non-beneficiaries). In the beneficiary families, the income derived only from the benefit of the BFP and the RCP with the BFP had a good performance in predicting $\mathrm{FI}$, covering the curve in $70 \%$ (IC95\% 0.57-0.82; $p=<0.03$ ) and $70 \%$ (IC95\% 0.59-0.82; $p=<0.02$ ), respectively. The sources of income of the nonbeneficiary families did not present a statistically significant performance in predicting $\mathrm{FI}$.
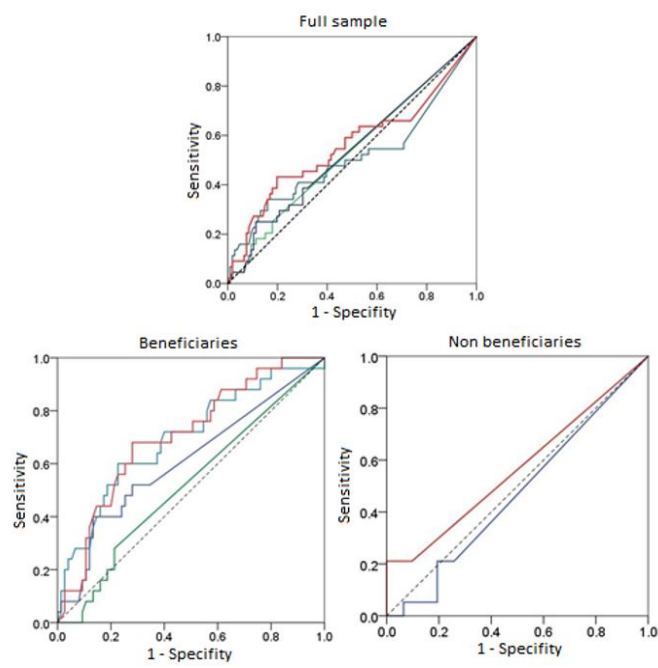

- Proportion of total income in relation to the income of the BFP

- Proportion of total income in relation to RCP income

- Proportion of total income in relation to salary income

-Proportion of total income in relation to the income of the BFP and the RCP

...50\% cutoff point for sensitivity and specificity

Figure 2. Proportion of total household income in relation to BFP, RCP and wage sources.

BFP - Bolsa Família Program; RCP - Renda Cidadã Program. 
Figure 3 shows the predictive power of the difference between income from wages in relation to household expenditures (complete and stratified sample - beneficiaries and non-beneficiaries). It was observed that, in the complete sample, the difference between the wage income and the rent and gas expenses were considered modest predictors, covering $67 \%$ (IC95\% 0.56-0.77) and 62\% (IC95\% 0.51-0.73, p = 0.03) of the area under the curve. On the other hand, among the beneficiary families of the BFP, the variable with the greatest predictive power was the difference between the income of salary and the expenses with rent and gas covering an area under the curve greater than $70 \%$. Also among beneficiary families, the variable that measured the difference between income from wages and rent expenditure almost reached $70 \%(0.69, \mathrm{IC} 95 \% 0.56-0.81, p=0.02)$.
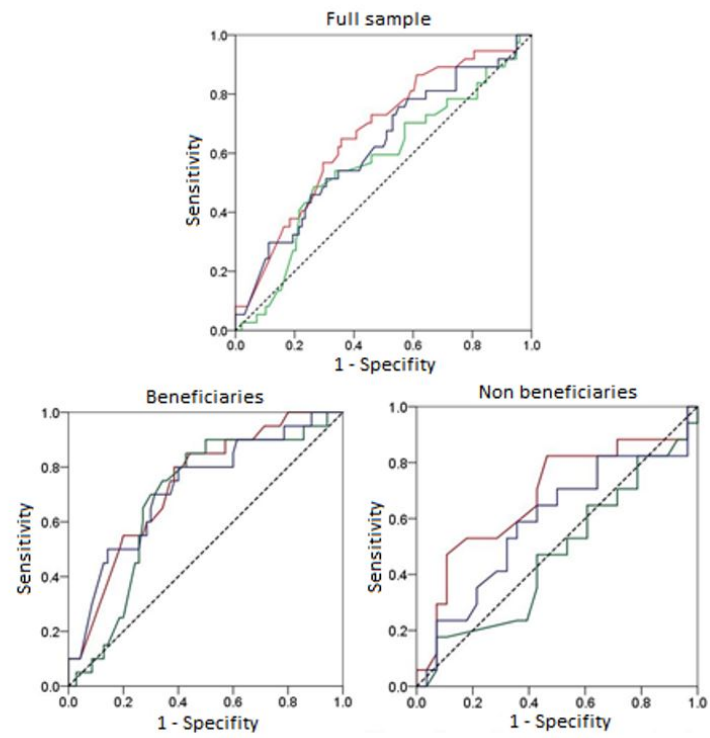

-Difference between rent income and rent expense

- Difference between the income from wages and food expenses

-Difference between wage income and gas spending

... 50\% cutoff point for sensitivity and specificity

Figure 3. Difference between income of families' salaries and expenses with rent, food and gas.

\section{Discussion}

Components of household income were confirmed as potential indicators complementary to the assessment of food and nutritional insecurity by BFIS. In this case, the expenses with rent and cooking gas were the components of better performance.

Among beneficiary families of the BFP, the proportion of income from this program, as well as the sum between the benefits of the BFP and the RCP, performed as acceptable indicators of MFI/SFI. Also among beneficiary families, the difference between the families' salaries and the rent and gas expenses presented an even higher performance as potential MFI/SFI indicators.

The main criterion for the inclusion of families in the BFP is the per capita income, at the time of the study, of up to $\mathrm{R} \$ 154.00$, and the income prior to receiving the benefit did not exceed $R \$ 462.00$. However, in the families studied, an increase of $R \$ 169.00$ in 
total income and an increase of $R \$ 343.30$ in the income of non-beneficiary families would still be necessary to cover food expenses.

The results of this study corroborate IBASE's (2009) findings, which shows the high expenditure on household food, averaging $\mathrm{R} \$ 200.00$ per month. In this study, the proportion of income spent on food was, on average, $43 \%$ in beneficiary families and $42 \%$ in income in non-beneficiary families, slightly below the proportion of income spent on food described in the IBASE study (2009) of $55.7 \%$.

In another study carried out in Viçosa, Minas Gerais state, in which the Brazilian Association of Research Companies (BARC) method was used to classify families at socioeconomic levels according to consumer goods, with $E$ being the highest level, the authors showed that $67 \%$ of families with socioeconomic level B were in SA, while $91 \%$ of families classified with socioeconomic level E were in FI (Souza et al., 2012).

The results of this study are in agreement with the previously cited studies, supporting the accuracy of the findings and the use of income as a potential indicator of $\mathrm{FI}$, although in these studies its predictive power has not been tested. Additionally, it is important to highlight that, through an advanced search in secure databases inside and outside the country, about scientific works that focused on the Bolsa Familia and the ROC Curve analysis, only one article was found, which made only an analysis of the need for beneficiaries to be included or not in the program (Almeida et al., 2016). In this sense, this work innovates when applying the ROC Curve for the prediction of indicators in social programs.

It was observed that the differences between wages and expenditures on food, rent, and gas can be important indicators of food and nutritional insecurity. In this study, the greater the difference between salary and rent and cooking gas expenses, the higher the proportion of families in MFI/SFI.

Panigassi et al. (2008) consider that the income indicator, despite having great utility for the definition of the population to be benefited by social programs, presents limitations. E.g. individuals exposed to social vulnerabilities, at risk of FI, may not be necessarily in this situation. This is the study of Schimidt et al. (2017), which addresses the question of focusing the BFP, which presents as an obstacle to the maintenance of families eligible to the program, due to the difficulty in the accuracy of their income data.

Therefore, in the individual's perception of $\mathrm{FI}$, the prioritization of other expenses such as the payment of rent, electricity, transportation, gas or others may be more important or necessary than the purchase of food. In addition, Pérez-Escamilla \& Segall-Corrêa (2008) emphasize BFIS's susceptibility to the interpretation of the layperson, since beneficiaries of the income transfer programs could assume that a positive response to their FS status may result in cancellation of the benefit.

\section{Conclusion}

The inclusion of quantitative indicators can complement the BFIS method, improving its accuracy and reducing user perception/interpretation bias. In this sense, income and its components such as rent and gas expenses, besides being reference measures for social vulnerability, were described in this study as having an acceptable predictive power of $\mathrm{FI}$, mainly among beneficiaries of the BFP.

The issue of income targeted at this population is also associated with food and nutritional insecurity in several studies mentioned here. Firstly, by the very condition of poverty and extreme poverty (classified by the BFP); and secondly, because they participate or come to participate in an income transfer program, and the bias in the 
individuals' responses to the perception of FI may occur, as well as the value of the income or expenses reported informally. However, most of the studies deal with the issue from the experience of technicians and managers of the program and the observation of a qualitative perspective.

This study's contribution was to measure and to develop a quantitative evaluation, giving an statistical treatment, bringing to the fore the components related to income and expenses that obtained better performance as predictors of $\mathrm{FI}$ for this population, also stressing that for the beneficiaries of social programs, in this case, Bolsa Família, the expenses influence much more in their state of alimentary and nutritional insecurity. Perhaps one way to seek to deepen income, expenditure and nutritional and nutritional insecurity relationships for beneficiaries of income transfer programs is to include the application of the BFIS in the Single Database, which already considers income and household expenditure information.

\section{References}

Almeida, A. T. C., Mesquita, S. P., \& Silva, M. V. B. (2016). Impactos do Programa Bolsa Família sobre a diversificação do consumo de alimentos no Brasil. Pesquisa e Planejamento Economico, 46(1), 7-39.

Altman, D. G. (1991). Practical Statistics for Medical Research. London: Chapman Hall.

Anderson, S. A. (1990). Core indicators of nutritional state for difficult-to-sample populations. The Journal of Nutrition, 120(Suppl. 11), 1559-1600. http://dx.doi.org/10.1093/jn/120.suppl_11.1555. PMid:2243305.

Brasil. (2006, 18 de setembro). Lei no 11.346, de 15 de setembro de 2006. Cria o Sistema Nacional de Segurança Alimentar e Nutricional - SISAN com vistas em assegurar o direito humano à alimentação adequada e dá outras providências. Brasília, DF: Diário Oficial da República Federativa do Brasil.

Brasil. (2011). Orientações para coleta e análise de dados antropométricos em serviços de saúde: norma técnica do Sisvan. Brasília: Ministério da Saúde.

Brasil. (2017). Programa Bolsa Família. Brasília: Ministério do Desenvolvimento Social.

Cardozo, D. R. (2016). Renda, consumo alimentar e estado nutricional como indicadores complementares à insegurança alimentar e nutricional no Programa Bolsa Família (Tese de doutorado). Universidade Estadual Paulista, Araraquara.

Cotta, R. M. M., \& Machado, J. C. (2013). The Bolsa Família cash transfer program and food and nutrition security in Brazil: a critical review of theliterature. Revista Panamericana de Salud Pública, 33(1), 54-60. http://dx.doi.org/10.1590/S1020-49892013000100008. PMid:23440158.

Fávero, L. P., \& Belfiore, P. (2017). Manual de análise de dados: estatística e modelagem multivariada com Excel*, SPSS* e Stata*. Rio de Janeiro: Elsevier.

Galesi, L. F., Quesada, K. R., \& Oliveira, M. R. M. (2009). Indicadores de segurança alimentar e nutricional. Simbio-Logias, 2(1), 1-10.

Gross, R., Schoeneberger, H., Pfeifer, H., \& Hans-Joachim, A. (2000). The four dimensions of food and nutrition security: definitions and concepts. Rome: FAO. Retrieved in 2018, October 20, from http://www.fao.org/docrep/013/al936e/al936e00.pdf

Hu, F. B., \& Willett, W. C. (2002). Optimal diets for prevention of coronary heart disease. Journal of the American Medical Association, 288(20), 2569-2578. http://dx.doi.org/10.1001/jama.288.20.2569. PMid:12444864. 
Instituto Brasileiro de Análises Sociais e Econômicas - IBASE. (2009). $2^{a}$ etapa da pesquisa Repercussões do programa Bolsa Família na segurança alimentar e nutricional das famílias beneficiadas. Rio de Janeiro: IBASE.

Instituto Brasileiro de Geografia e Estatística - IBGE. (2004). Pesquisa de Orçamentos Familiares (POF) 2002-2003: análise da disponibilidade domiciliar de alimentos e do estado nutricional no Brasil. Brasília: MPOG/IBGE.

Jones, A. D., Ngure, F. M., Pelto, G., \& Young, S. L. (2013). What are we assessing when we measure food security? A Compendium an review of current metrics. Advances in Nutrition 4(5), 481-505. http://dx.doi.org/10.3945/an.113.004119. PMid:24038241.

Lignani, J. B., Sichieri, R., Burlandy, L., \& Salles-Costa, R. (2011). Changes in food consumption among the Programa Bolsa Família participant families in Brazil. Public Health Nutrition, 14(5), 785-792. http://dx.doi.org/10.1017/S136898001000279X. PMid:21129236.

Martinez, E. Z., Louzada-Neto, F., \& Pereira, B. B. (2003). A curva ROC para testes diagnósticos. Cadernos Saúde Coletiva, 11(1), 7-31.

Organização das Nações Unidas para Alimentação e Agricultura - ONU/FAO. (2014). O estado da segurança alimentar e nutricional no Brasil: um retrato multidimensional. Brasília: ONU/FAO.

Organización de las Naciones Unidas para la Alimentación y la Agricultura - ONU/FAO. Organización Panamericana de la Salud - OPS. (2017). Panorama de la seguridad alimentaria y nutricional en América Latina y el Caribe. Santiago de Chile: FAO/OPS.

Panigassi, G., Segall-Côrrea, A. M., Marin-León, L., Pérez-Escamilla, R., Sampaio, M. F. A., \& Maranha, L. K. (2008). Insegurança alimentar como indicador de iniquidade: análise de inquérito populacional. Cadernos de Saude Publica, 24(10), 2376-2384. http://dx.doi.org/10.1590/S0102-311X2008001000018. PMid:18949239.

Pérez-Escamilla, R., \& Segall-Corrêa, A. M. (2008). Food insecurity measurement and indicators. Revista de Nutrição, 21, 15s-26s. http://dx.doi.org/10.1590/S141552732008000700003.

Schimidt, K. H., Labrecque, J., Santos, I. S., Matijasevich, A., Barros, F. C., \& Barros, A. J. D. (2017). Foco e cobertura do Programa Bolsa Família na coorte de nascimentos de Pelotas, 2004. Revista de Saúde Pública, 51, 22.

Segall-Corrêa, A. M. (2007). Insegurança alimentar medida a partir da percepção das pessoas. Estudos Avançados, 21(60), 143-154. http://dx.doi.org/10.1590/S010340142007000200012.

Segall-Corrêa, A. M., \& Marin-León, L. (2009). Food security in Brazil: the proposal and application of the Brazilian Food Insecurity Scale from 2003 to 2009. Segurança Alimentar e Nutricional, 16(2), 1-19.

Segall-Corrêa, A. M., Pérez-Escamilia, R., Maranha, L. K., Sampaio, M. F. A., Yuyana, L., \& Alencar, F. (2003). Projeto: acompanhamento e avaliação da segurança alimentar de famílias brasileiras: validação de metodologia e de instrumento de coleta de informação. Campinas: Departamento de Medicina Preventiva e Social, Universidade Estadual de Campinas.

Souza, N. N., Dias, M. M., Sperandio, N., Franceschini, S. C. C., \& Priore, S. E. (2012). Perfil socioeconômico e insegurança alimentar e nutricional de famílias beneficiárias do Programa Bolsa Família no município de Viçosa, Estado de Minas Gerais, Brasil, em 2011: um estudo epidemiológico transversal. Epidemiologia e Serviços de Saúde, 21(4), 655662. http://dx.doi.org/10.5123/S1679-49742012000400015.

Sperandio, N., \& Priore, S. E. (2015). Prevalence of household food insecurity and associated factors among bolsa familia program families with preschool in Viçosa. Epidemiologia e Serviços de Saúde, 24, 739-748. http://dx.doi.org/10.5123/S1679-49742015000400016. 
Traldi, D. R. C., Almeida, L. M. M. C., \& Ferrante, V. L. S. B. (2012). Repercussions of the Bolsa Familia Program in the city of Araraquara, SP: a look at the food security and nutritional status of beneficiaries. Interações, 13(1), 23-37.

Vannier-Santos, M. C. (2007). Indicadores de Segurança Alimentar e Nutricional: uma análise das possibilidades e limites a partir da POF 2002-2003 (Dissertação de mestrado). Instituto Brasileiro de Geografia e Estatística, Escola Nacional de Ciências Estatísticas, Rio de Janeiro.

Ziegler, J. (2003). Le droit à l'alimentation. Paris: Mille et Une Nuits.

Zweig, M. H., \& Campbell, G. (1993). Receiver-Operating Characteristic (ROC) plots: a fundamental evaluation tool in clinical medicine. Clinical Chemistry, 39(4), 561-577. http://dx.doi.org/10.1093/clinchem/39.4.561. PMid:8472349. 
Appendix A. Supplementary figure.

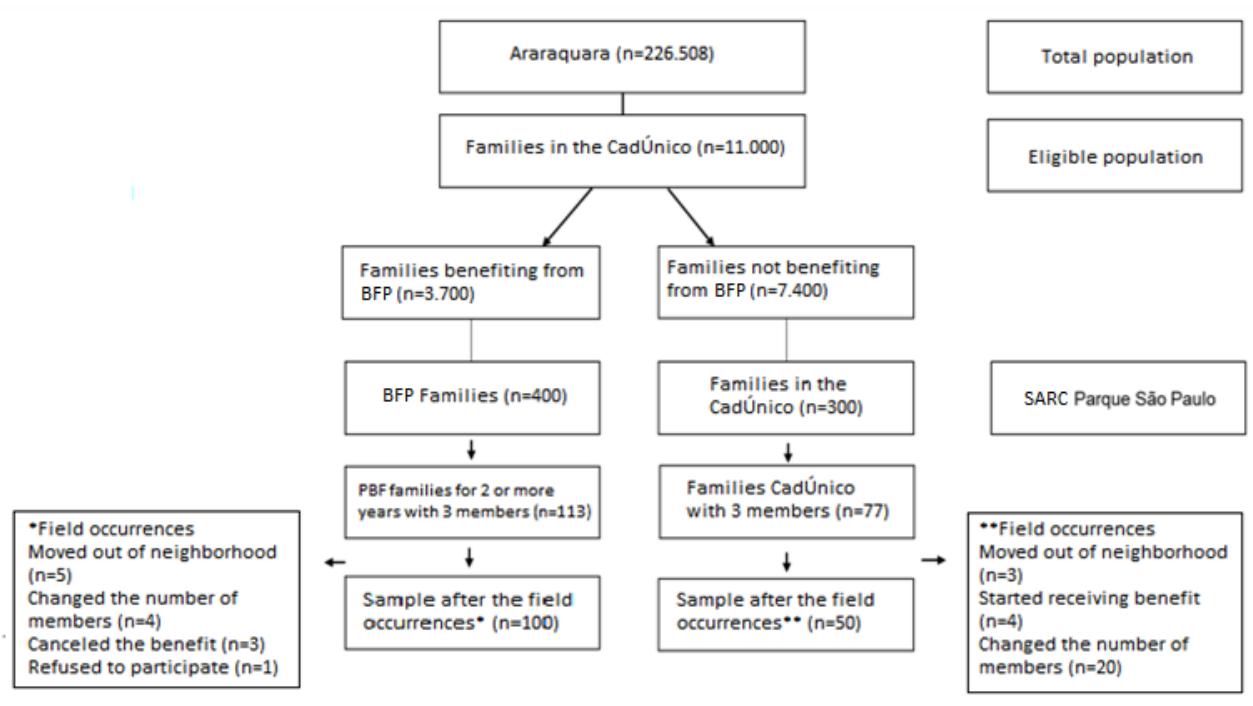

Figure 1A. Sampling the study population. 
Appendix B. Supplementary table.

Table 1B. Averages, standard deviation and correlation coefficient between potential indicators of food insecurity in the population and according to the receipt or not of the BFP.

\begin{tabular}{|c|c|c|c|c|c|c|c|c|c|}
\hline & \multicolumn{3}{|c|}{ Population } & \multicolumn{3}{|c|}{ Beneficiaries of BFP } & \multicolumn{3}{|c|}{ Non-beneficiaries of BFP } \\
\hline & Mean \pm SD & $r$ & $p$ & Mean \pm SD & $r$ & $p$ & Mean \pm SD & $r$ & $p$ \\
\hline Total expenditures at home $(R \$)$ & $614.4 \pm 298.7$ & -0.17 & 0.03 & $572.5 \pm 270.7$ & -0.22 & 0.03 & $698.1 \pm 335.4$ & -0.16 & 0.30 \\
\hline Value of Bolsa Família $(\mathrm{R} \$)$ & $78.9 \pm 75.6$ & -0.01 & 0.90 & $118.4 \pm 62.2$ & 0.10 & 0.30 & - & - & - \\
\hline Value of Renda Cidadã (R\$) & $18.8 \pm 50.7$ & 0.14 & 0.10 & $22.6 \pm 58.6$ & 0.15 & 0.20 & $11.2 \pm 28$ & 0.15 & 0.30 \\
\hline Value of other benefits ( $R \$$ ) & $98.0 \pm 182.0$ & -0.02 & 0.80 & $111.6 \pm 185.3$ & 0.14 & 0.20 & $71.0 \pm 173.8$ & -0.24 & 0.09 \\
\hline Wage $(\mathrm{R} \$)$ & $61.4 \pm 465.8$ & -0.30 & $<0.01$ & $511.6 \pm 480.6$ & -0.40 & $<0.01$ & $817.0 \pm 360.3$ & -0.24 & 0.10 \\
\hline \multicolumn{10}{|c|}{ Proportion of total income spent with: } \\
\hline Gas (\%) & $4.3 \pm 3.1$ & 0.23 & $<0.05$ & $4.6 \pm 3.3$ & 0.27 & 0.01 & $3.8 \pm 2.5$ & 0.18 & 0.20 \\
\hline Rent (\%) & $10.8 \pm 22.9$ & 0.21 & 0.01 & $8.8 \pm 19.2$ & 0.14 & 0.20 & $14.8 \pm 28.7$ & 0.29 & 0.04 \\
\hline Rent and Gas (\%) & $15.1 \pm 23$ & 0.35 & $<0.01$ & $13.4 \pm 19.4$ & 0.34 & $<0.01$ & $18.7 \pm 28.8$ & 0.35 & 0.01 \\
\hline Food $(\%)$ & $42.3 \pm 26.9$ & 0.02 & 0.90 & $41.9 \pm 28.3$ & 0.11 & 0.30 & $43.1 \pm 24.0$ & -0.18 & 0.30 \\
\hline Water (\%) & $7.7 \pm 7.0$ & 0.14 & 0.10 & $8.4 \pm 7.2$ & 0.18 & 0.08 & $6.4 \pm 6.5$ & 0.09 & 0.50 \\
\hline Electric Energy (\%) & $10.4 \pm 7.7$ & 0.18 & 0.03 & $11.6 \pm 7.9$ & 0.23 & 0.02 & $8.0 \pm 6.8$ & 0.13 & 0.40 \\
\hline Education (\%) & $2.5 \pm 5.8$ & -0.05 & 0.50 & $2.4 \pm 6.1$ & 0.03 & 0.80 & $2.7 \pm 5.1$ & -0.23 & 0.10 \\
\hline Health (\%) & $4.1 \pm 9.7$ & -0.13 & 0.10 & $3.1 \pm 6.5$ & -0.07 & 0.50 & $6.3 \pm 14.0$ & -0.23 & 0.10 \\
\hline Telephone (\%) & $2.0 \pm 4.1$ & -0.13 & 0.10 & $1.9 \pm 4.3$ & -0.07 & 0.50 & $2.1 \pm 3.7$ & -0.24 & 0.10 \\
\hline Other expenses (\%) & $7.8 \pm 14.5$ & -0.09 & 0.30 & $8.2 \pm 15.4$ & -0.07 & 0.50 & $7.2 \pm 12.7$ & -0.12 & 0.40 \\
\hline \multicolumn{10}{|c|}{ Proportion of total income from: } \\
\hline Bolsa Família Program (\%) & $14.2 \pm 17.6$ & 0.11 & 0.20 & $21.3 \pm 17.7$ & 0.37 & $<0.01$ & - & - & - \\
\hline Renda Cidadã Program (\%) & $3.6 \pm 11.6$ & 0.14 & 0.10 & $3.7 \pm 9.7$ & 0.12 & 0.20 & $3.4 \pm 14.7$ & 0.17 & 0.20 \\
\hline Wage $(\%)$ & $15.1 \pm 25.8$ & 0.03 & 0.80 & $19.1 \pm 27.9$ & 0.16 & 0.10 & $7 \pm 19$ & -0.23 & 0.10 \\
\hline Bolsa Família and Renda Cidadã (\%) & $17.8 \pm 21.6$ & 0.19 & 0.02 & $25 \pm 21$ & 0.40 & $<0.01$ & - & - & - \\
\hline \multicolumn{10}{|c|}{ Difference between Bolsa Familia income and expenses with: } \\
\hline Food $(\mathrm{R} \$)$ & $-227.7 \pm 179.9$ & 0.24 & $<0.05$ & $-169.9 \pm 161.4$ & 0.32 & $<0.02$ & $-343.3 \pm 159.3$ & 0.39 & $<0.09$ \\
\hline Gas (R\$) & $50.9 \pm 78.3$ & 0.01 & 0.90 & $91.1 \pm 65$ & 0.11 & 0.30 & $-29.6 \pm 14.9$ & 0.13 & 0.40 \\
\hline Rent $(\mathrm{R} \$)$ & $-0.5 \pm 184.4$ & -0.11 & 0.20 & $53.1 \pm 157.7$ & 0.00 & 0.90 & $-107.6 \pm 188.5$ & -0.30 & 0.03 \\
\hline \multicolumn{10}{|c|}{ Difference between the Income of the Renda Cidadã Program and expenses with: } \\
\hline Food $(R \$)$ & $-286.7 \pm 161.1$ & 0.32 & $<0.01$ & $-264.7 \pm 154.3$ & 0.34 & $<0.01$ & $-330.8 \pm 166.9$ & 0.36 & 0.02 \\
\hline Gas (R\$) & $-9.3 \pm 51.1$ & 0.13 & 0.10 & $-4.7 \pm 58.2$ & 0.15 & 0.10 & $-18.4 \pm 31.1$ & 0.11 & 0.40 \\
\hline Rent $(\mathrm{R} \$)$ & $-60.6 \pm 166.6$ & -0.11 & 0.20 & $-42.7 \pm 151.6$ & -0.05 & 0.60 & $-96.4 \pm 189.7$ & -0.20 & 0.20 \\
\hline \multicolumn{10}{|c|}{ Difference between the income of the Bolsa Familia and Renda Cidadã Programs and expenses with: } \\
\hline Food $(R \$)$ & $-208.6 \pm 193.5$ & 0.25 & $<0.03$ & $-147.4 \pm 176.8$ & 0.33 & $<0.02$ & - & - & - \\
\hline Gas (R\$) & $69.7 \pm 99.3$ & 0.05 & 0.60 & $113.7 \pm 92.1$ & 0.13 & 0.20 & $-18.4 \pm 31.1$ & 0.11 & 0.40 \\
\hline Rent $(R \$)$ & $18.3 \pm 194.8$ & -0.10 & 0.20 & $75.7 \pm 171.3$ & -0.01 & 0.90 & $-96.4 \pm 189.7$ & -0.20 & 0.20 \\
\hline \multicolumn{10}{|c|}{ Difference between salary income and expenses with: } \\
\hline Food $(\mathrm{R} \$)$ & $331.6 \pm 400.5$ & -0.19 & 0.02 & $254.3 \pm 423.5$ & -0.33 & $<0.01$ & $486.2 \pm 298.6$ & -0.02 & 0.90 \\
\hline Gas $(R \$)$ & $585.3 \pm 463.7$ & -0.30 & $<0.01$ & $484.3 \pm 479.3$ & -0.39 & $<0.01$ & $787.4 \pm 356.7$ & -0.24 & 0.10 \\
\hline Rent (R\$) & $534 \pm 473.1$ & -0.36 & $<0.01$ & $446.3 \pm 481.1$ & -0.42 & $<0.01$ & $709.4 \pm 407.2$ & -0.37 & $<0.08$ \\
\hline
\end{tabular}

BFP - Bolsa Família Program; SD - Standard Deviation; $p$ - $p$-value; $r$ - Pearson's correlation coefficient 